\title{
Culture conditions affecting the in vitro propagation of Amyloodinium ocellatum
}

\author{
Edward J. Noga \\ Department of Companion Animal and Special Species Medicine, College of Veterinary Medicine, North Carolina State \\ University, Raleigh, North Carolina 27605, USA
}

\begin{abstract}
Amyloodinium ocellatum, a common dinoflagellate parasite of marine fishes, could be propagated in walking catfish gill (G1B) cell culture using a very simple salt solution consisting of a 1:1 mixture of Hank's Balanced Salt Solution and artificial seawater. This culture system did not require the addition of serum or other additives, although significant amounts of trace metals were present as contaminants of the reagent-grade salts used to prepare the salt solution. The salt composition of the medium was important to parasite survival even while the parasites were feeding on the host. The best media for continuous propagation were proportionately higher in $\mathrm{K}, \mathrm{Mg}, \mathrm{Ca}$, and $\mathrm{SO}_{4}$. The relatively simple composition of this culture system may greatly facilitate the study of $A$. ocellatum because of its strong resemblance to natural environmental conditions.
\end{abstract}

\section{INTRODUCTION}

Amyloodinium ocellatum is a euryhaline dinoflagellate that parasitizes a wide range of estuarine and marine fishes (Lawler 1980, Lauckner 1984). The parasitic stage (trophont) feeds on host epithelial tissues of the skin and gills for up to several days, after which it detaches from the host and forms a dividing cyst (tomont) in the substrate. Motile dinospores are released from the tomont after several more days. Dinospores can infect new hosts, forming trophonts to continue the life cycle.

The wide tolerance of Amyloodinium ocellatum to varying osmotic conditions, combined with its cosmopolitan host range, were probably important in facilitating the establishment of an in vitro culture system (Noga 1987, Noga \& Bower 1987). This culture system is very similar cytopathologically and developmentally to natural infections of amyloodiniosis. Parasites passaged over 100 times in vitro have remained infective for fish, and have remained similar in appearance to wild isolates propagated on fish, suggesting that this culture has not changed significantly since isolation. The in vitro culture system was based upon the use of a gill cell line, G1B (Noga \& Hartmann 1981), as a host (feeder) layer for the parasite, overlain by a culture medium consisting of a seawater/cell culture medium mixture. This unde- fined medium contained many components, including various trace minerals, serum factors, and other nutrients. The purpose of this paper is to report that much simpler media are capable of supporting $A$. ocellatum in vitro.

\section{MATERIALS AND METHODS}

Experimental media. Several salt solutions and more complex media were tested for their ability to support growth of Amyloodinium ocellatum (Table 1). IO was an artificial seawater solution (Instant Ocean, Aquarium Systems, Mentor, $\mathrm{OH}$, USA) that contained both major and trace minerals (Anon. 1985). IO2 was an artificial seawater solution prepared from major mineral salts. This medium was a modification of the GP medium formulated by Spotte (1979). The chemical composition of $1 \mathrm{O} 2$ was $\mathrm{NaCl} 26.00 \mathrm{~g} \mathrm{l}^{-1}, \mathrm{KCl} 0.68 \mathrm{~g} \mathrm{l}^{-1}$, $\mathrm{CaCl}_{2} \cdot \mathrm{H}_{2} \mathrm{O} 1.46 \mathrm{~g} \mathrm{l}^{-1}, \mathrm{MgSO}_{4} \cdot 7 \mathrm{H}_{2} \mathrm{O} 6.58 \mathrm{gl}^{-1}$, and $\mathrm{NaHCO}_{3} 0.18 \mathrm{~g} \mathrm{l}^{-1}$.

Hank's Balanced Salt Solution (HBSS) was a physiological saline originally developed for use in mammalian cell culture (Merchant et al. 1964), but also used extensively in fish cell culture. HBSSM was an HBSS solution to which $6.5 \mathrm{~g} \mathrm{l}^{-1} \mathrm{NaCl}$ was added. $\mathrm{H}$ was a modified Ham's F-12 cell culture medium (Ham 1965 ) in which all components were present at $52 \%$ of 
Table 1. Chemical composition $\left(\mathrm{g} \mathrm{l}^{-1}\right)$ of media used for Amyloodinium ocellatum propagation experiments

\begin{tabular}{|c|c|c|c|c|c|c|c|c|}
\hline \multirow[t]{2}{*}{ Component } & \multicolumn{8}{|c|}{ Medium } \\
\hline & $\mathrm{H}^{\dot{a}}$ & IO & 102 & HBSS & HBSSM & $102 / \mathrm{HBSS}$ & $\mathrm{IO} 2 / \mathrm{HBSS}-\mathrm{A}$ & $\mathrm{IO} / \mathrm{H}^{\mathrm{a}}$ \\
\hline $\mathrm{Na}$ & 1.53 & 10.73 & 10.35 & 3.29 & 5.87 & 6.82 & 5.12 & 6.13 \\
\hline$K$ & 0.05 & 0.39 & 0.35 & 0.23 & 0.23 & 0.29 & 0.22 & 0.17 \\
\hline $\mathrm{Cl}$ & 2.38 & 18.42 & 18.39 & 5.10 & 9.02 & 11.75 & 8.81 & 10.40 \\
\hline $\mathrm{Ca}$ & 0.01 & 0.39 & 0.40 & 0.05 & 0.05 & 0.22 & 0.17 & 0.20 \\
\hline $\mathrm{Mg}$ & 0.07 & 1.33 & 1.21 & 0.02 & 0.02 & 0.62 & 0.47 & 0.70 \\
\hline $\mathrm{SO}_{4}$ & 0 & 2.75 & 2.56 & 0.08 & 0.08 & 1.32 & 0.99 & 1.38 \\
\hline $\mathrm{PO}_{4}$ & 0.05 & 0.002 & 0 & 0.06 & 0.06 & 0.03 & 0.02 & 0.03 \\
\hline $\mathrm{HCO}_{3}^{\mathrm{b}}$ & 2.20 & 0.14 & 0.13 & 0.25 & 0.25 & 0.19 & 0.14 & 1.17 \\
\hline Glucose & 1.80 & 0 & 0 & 1.00 & 1.00 & 0.50 & 0.38 & 0.90 \\
\hline Phenol red & 0.001 & 0 & 0 & 0.01 & 0.01 & 0.005 & 0.005 & 0.0005 \\
\hline HEPES & 5.94 & 0 & 0 & 0 & 0 & 0 & 0 & 2.97 \\
\hline Other additives & $N^{c}$ & $T^{d}$ & 0 & 0 & 0 & 0 & 0 & $1 / 2 \mathrm{TN}^{\mathrm{e}}$ \\
\hline Osmolarity (mOsm) & 230 & 938 & 927 & 277 & 458 & 610 & 458 & 470 \\
\hline \multicolumn{9}{|c|}{$\begin{array}{l}\text { a Concentrations of salts in these media are approximations due to the presence of serum, which varies slightly in composition } \\
\text { b Approximate concentration of bicarbonate present; actual concentration is dependent upon metabolic activity and pH } \\
{ }^{\mathrm{C}} \mathrm{N}=\text { nutrients, including various amino acids, vitamins, serum components, and sugars (Ham 1965, Noga \& Hartmann 1981) } \\
{ }^{\mathrm{d}} \mathrm{T}=\text { trace minerals including } \mathrm{Al}, \mathrm{Bo}, \mathrm{Ba}, \mathrm{Cr}, \mathrm{Co}, \mathrm{Fe}, \mathrm{Li}, \mathrm{Mn}, \mathrm{Mb}, \mathrm{Ni}, \mathrm{P} \text {, Si. Sr, Sn, Vd, and } \mathrm{Zn} \text { present as contaminants in this } \\
\text { technical grade preparation (Anon. } 1985 \text { ) } \\
\text { e } 1 / 2 \mathrm{TN}=1: 1 \text { mixture of } \mathrm{OO} \text { and } \mathrm{H} \text { media which results in a } 50 \% \text { dilution of components in each medium }\end{array}$} \\
\hline
\end{tabular}

the standard concentration; in addition, it contained $23 \mathrm{mM}$ HEPES buffer, $25 \mathrm{mM} \mathrm{NaHCO} 3,100 \mathrm{U} \mathrm{ml}^{-1}$ penicillin, $100 \mu \mathrm{g} \mathrm{ml^{-1 }}$ streptomycin sulfate and $9 \%$ fetal bovine serum (Noga \& Hartmann 1981).

Media were prepared from reagent grade chemicals, adjusted to $\mathrm{pH} 7.3$ to 7.5 with $\mathrm{NaOH}$ or $\mathrm{HCl}_{\text {, filter- }}$ sterilized, and then stored at $4{ }^{\circ} \mathrm{C}$ prior to use, with the following exceptions: IO was prepared from a commercial brand of sea salts, which contained technical grade reagents (Edward Mowka, Aquarium Systems, Mentor, $\mathrm{OH}$, USA, pers. comm.). The $\mathrm{pH}$ of $\mathrm{IO}$ and $\mathrm{IO} 2$ was 7.6 to 7.8. HBSS and HBSSM were sterilized by autoclaving.

$\mathrm{IO} / \mathrm{H}$ was a $1: 1$ mixture of $\mathrm{IO}$ and $\mathrm{H}$ media; $\mathrm{IO} 2 /$ HBSS was a 1:1 mixture of IO2 and HBSS. IO2/HBSS-A was a solution of IO2/HBSS diluted by $25 \%$ with deionized water, making the concentration of all constituents $75 \%$ of that in IO2/HBSS. Osmolarities of the media were measured by freezing point depression using an osmometer (Precision Systems, Sudbury, MA, USA).

Culture of host cells and parasites. Amyloodinium ocellatum strain 85-1, derived from fish-cultured strain DC-1 of Bower et al. (1987), was maintained by serial passage on the fish gill cell line G1B. At the time experiments were initiated, strain $85-1$ had been passaged in vitro ca 60 to 80 times. Details of the culture methodology have been reported previously (Noga 1987). Briefly, $25 \mathrm{~cm}^{2}$ monolayers of $\mathrm{G} 1 \mathrm{~B}$ cells in $\mathrm{IO} / \mathrm{H}$ were infected with 50000 to 100000 A. ocellatum dinospores at $25^{\circ} \mathrm{C}$. Tomonts were harvested after 2 to $5 \mathrm{~d}$, concentrated by gentle centrifugation, and incu- bated in a single well of a 24 -well tissue culture plate (Costar Plastics, Cambridge, MA, USA). Dinospores were used within $24 \mathrm{~h}$ of excystment. Dinospores were counted with a hemacytometer and then diluted in the various media just prior to initiation of an experiment. All experiments were performed at $25^{\circ} \mathrm{C}$.

Determination of plating efficiency. We examined the ability of Amyloodinium ocellatum to differentiate from dinospores to trophonts in the presence of different culture media.

Gill cells were seeded into 48-well tissue culture plates at a concentration of 250000 cells in $0.50 \mathrm{ml}$ of $\mathrm{H}$ medium. The next day, $0.50 \mathrm{ml}$ of the medium to be tested was added to each well in order to acclimate the cells to the test medium. After a further 3 to $7 \mathrm{~d}$, each well was rinsed twice with $0.50 \mathrm{ml}$ of test medium and then $1.0 \mathrm{ml}$ of test medium was added to each well. Finally, a $0.10 \mathrm{ml}$ aliquot of test medium containing 150 dinospores was added to each well. The total dilution of $\mathrm{IO} / \mathrm{H}$ in various test media resulted in the final medium in each well consisting of at least $98 \%$ test medium. Plates were sealed with plastic tape and incubated at $25^{\circ} \mathrm{C}$.

The number of trophonts (i.e. differentiated dinospores) was counted in each well after $24,48,72$, and $96 \mathrm{~h}$. Mean percentage differentiation was calculated relative to the total number of dinospores added to the wells. The significance of various treatments from one another was tested by converting all percentage values to arc-sine and performing analysis of variance on the transformed values. The $t$-value for paired treatments was then calculated. 
Determination of long-term survival. Gill cells were seeded into triplicate $25 \mathrm{~cm}^{2}$ plastic tissue culture flasks (Corning Plastics, Corning, NY, USA) at a concentration of $2.5 \times 10^{6}$ cells in $5 \mathrm{ml}$ of $\mathrm{H}$ medium. The medium was changed weekly. Two weeks or later after seeding, the medium was diluted 1:1 with various experimental media. Within $1 \mathrm{wk}$ of being diluted, each flask was rinsed $3 x$ with $3 \mathrm{ml}$ of HBSS and $1 x$ with $3 \mathrm{ml}$ of test medium. Five $\mathrm{ml}$ of test medium was then added to each flask, followed by 300 dinospores in $0.10 \mathrm{ml}$ of test medium. The $\mathrm{pH}$ of all cultures was maintained between 7.3 and 7.5 by the addition of $1.4 \% \mathrm{NaHCO}_{3}$, as needed.

Cultures were examined every other day for the presence of viable trophonts. A viable trophont was defined as one which exhibited visible movement. While trophonts remained in the same location (i.e. did not migrate) once they attached to the monolayer, they did move. This movement consisted of a twisting and turning around the base of the parasite. Trophonts which were near death showed considerably less movement. The presence and appearance of dinospores and tomonts were also noted. All observations were made with a Nikon Diaphot inverted phase contrast microscope (Nippon Kogaku K. K., Tokyo, Japan).

When ca $95 \%$ of the G1B cell monolayer had been killed by the parasites in one of the 3 flasks of a replicate, an aliquot of the dinospores in that flask was diluted in fresh test medium to a concentration of 300 dinospores $\mathrm{ml}^{-1}$. Of this suspension, $0.1 \mathrm{ml}$ was then added to triplicate flasks that were conditioned as described previously. This procedure was repeated for up to $84 \mathrm{~d}$ or until no viable parasites were present.

Trace mineral concentrations in cultures. Reagentgrade chemicals are often contaminated with small but significant amounts of heavy metals and other minerals. Thus, we estimated the potential contribution of such contaminants to the trace mineral requirements of the parasite. Triplicate G1B cultures in $25 \mathrm{~cm}^{2}$ flasks were adapted to IO2/HBSS medium as described previously. After $3 \mathrm{~d}$ incubation in fullstrength IO2/HBSS, the culture supernatant and cell monolayer were analyzed separately for total iron and copper concentrations using atomic absorption spectroscopy (McGahan \& Bito 1983, McGahan \& Fleisher 1986). Triplicate samples of fresh IO2/HBSS medium were also analyzed. Cell culture monolayers were dissolved in a combination of $75 \mu \mathrm{l}$ of $70 \%$ nitric acid, $150 \mu \mathrm{l}$ of $30 \%$ hydrogen peroxide, and $75 \mu \mathrm{l}$ of deionized water. The sample was incubated at room temperature for $1 \mathrm{~h}$, boiled at $100^{\circ} \mathrm{C}$ for $5 \mathrm{~min}$, allowed to cool, and then analyzed for metal content as described above.

\section{RESULTS}

\section{Plating efficiency of dinospores}

The ability of dinospores to differentiate into trophonts was influenced by the culture medium used to incubate the parasites (Fig. 1). The medium which

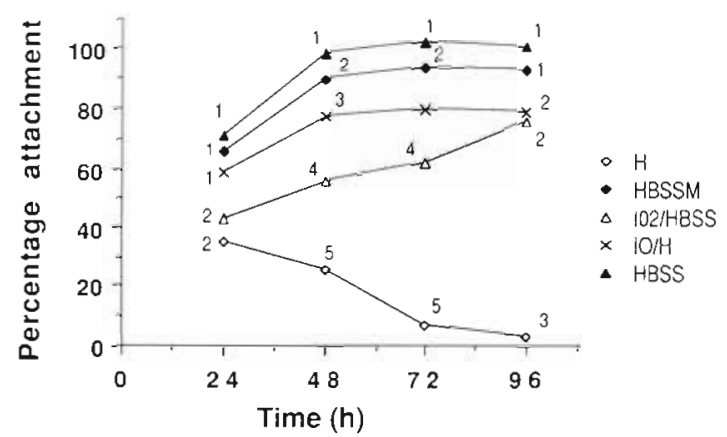

Fig. 1. Amyloodinium ocellatum. Plating efficiency of dinospores in various culture media. Each point represents the percentage of dinospores which differentiated into trophonts at various time intervals $(n=8$ to 16 replicates for each medium). Test conditions at the same time interval with different numbers are significantly different from one another

$$
(p<0.01)
$$

produced the highest percentage of trophonts was HBSS, a relatively low osmolarity, physiological saline. Virtually $100 \%$ of all dinospores differentiated into trophonts within $48 \mathrm{~h}$ of seeding into HBSS. HBSSM, which was HBSS supplemented with more $\mathrm{NaCl}$, produced slightly lower attachment (about $90 \%$ ). In the seawater-culture medium mixture, $\mathrm{IO} / \mathrm{H}$, and the salt mixture IO2/HBSS, a maximum of ca $80 \%$ differentiation resulted. The numbers of trophonts in all cultures increased over time except in those with $\mathrm{H}$ medium, where there was a progressive, rapid, decline in the number of trophonts present.

\section{Survival of parasites in long-term culture}

The ability of Amyloodinium ocellatum to complete its life cycle varied considerably depending upon the type of medium used (Table 2). The artificial seawater solutions IO and IO2 were acutely toxic to G1B cells and thus did not support $A$. ocellatum survival. Conversely, $\mathrm{H}$ and HBSS were nontoxic to G1B cells but did not support continued growth of $A$. ocellatum. While viable trophonts were present in both HBSS and HBSSM for over 2 mo, many trophonts exhibited abnormal, asynchronous divisions (Fig. 2B, C, D), which failed to produce viable dinospores. Few dinospores were produced in HBSS cultures and all parasites died before $95 \%$ of the G1B monolayer was killed. 
Table 2. Ability of various culture media to support the longterm survival of Amyloodinium ocellatum

\begin{tabular}{|c|c|c|}
\hline Medium & $\begin{array}{l}\text { Mean survival time } \\
(\mathrm{d})^{\mathrm{a}}\end{array}$ & $\begin{array}{l}\text { Growth rate } \\
(\text { d })^{b}\end{array}$ \\
\hline $\mathrm{H}$ & $<1$ & - \\
\hline 10 & 0 & - \\
\hline $\mathrm{IO} 2$ & $<1$ & - \\
\hline HBSS & 69 & - \\
\hline HBSSM & $>84$ & 69 \\
\hline $\mathrm{IO} / \mathrm{H}$ & $>84$ & 13 \\
\hline $\mathrm{IO} 2 / \mathrm{HBSS}$ & $>84$ & 1.2 \\
\hline IO2/HBSS-A & $>84$ & 14 \\
\hline \multicolumn{3}{|c|}{$\begin{array}{l}\text { Mean survival time }=\text { mean total number of days that } \\
\text { viable trophonts were observed in triplicate G1B cell } \\
\text { cultures having a given medium } \\
\text { b Growth rate = mean number of days required for the } \\
\text { parasites to destroy }>95 \% \text { of the G1B cell monolayer } \\
\text { Values are for triplicate cultures. Note that cultures } \\
\text { which did not survive until the end of the experiment } \\
\text { (i.e. did not survive } 84 \text { d) do not have a growth rate. } \\
\text { Growth rate of HBSSM is based upon a single passage of } \\
\text { all } 3 \text { cultures at Day } 69\end{array}$} \\
\hline
\end{tabular}

HBSSM cultures survived the entire experiment, but parasite growth was very slow; cultures were passaged only once. Similar abnormal parasites were also seen in these cultures.

Surprisingly, the artificial seawater, IO2/HBSS, was both nontoxic to G1B cells and allowed continuous growth of the parasites. In fact, the growth rate of Amyloodinium ocellatum in IO2/HBSS was virtually the same as those propagated in $\mathrm{IO} / \mathrm{H}$ (Table 2). Dilution of IO2/HBSS by $25 \%$ (IO2/HBSS-A) had little effect on the growth rate (Table 2 ). Some abnormal trophonts were also seen in IO/H, IO2/HBSS, and IO2/ HBSS-A, but they always constituted less than $5 \%$ of the population.

\section{Trace metal concentrations}

Total iron and copper concentrations in the G1B cell culture supernatants were very similar to those concentrations present as contaminants in fresh $102 / \mathrm{HBSS}$ (Table 3). Both of these metals were present in concen- trations that were similar to that normally present in seawater (Weast 1964). The contribution of the G1B cell monolayer to total metal present was somewhat variable.

\section{DISCUSSION}

The only media in which Amyloodinium ocellatum was successfully propagated were $10 / \mathrm{H}$, IO2/HBSS, and $102 / H B S S-A$, all of which produced fairly similar results in propagating the parasite. The generation time and life cycle of $A$. ocellatum in these cultures were similar to that reported for natural infections of amyloodiniosis (Lawler 1980, Lauckner 1984). $\mathrm{IO} / \mathrm{H}$ is a complex mixture containing major minerals, trace minerals, amino acids, vitamins, and other nutrients normally present in mammalian (as well as piscine) serum. Conversely, IO2/HBSS is an artificial seawater that is prepared from only major mineral salts, phosphate, glucose, and phenol red dye (Table 1). No other nutrients or trace minerals were added, although significant concentrations of the latter were present as contaminants. The ability of the G1B cell line to tolerate these media is quite remarkable, considering that the total nonmineral nutrient budget of a medium such as IO2/HBSS-A is a small amount $\left(0.38 \mathrm{~g} \mathrm{l}^{-1}\right)$ of glucose.

While the importance of environmental trace minerals to Amyloodinium ocellatum remains in question, this data does suggest that $A$. ocellatum may not be capable of assimilating nutrients such as vitamins or amino acids directly from sea water, in contrast to many free-living dinoflagellates (Provasoli 1958, Guillard \& Keller 1984). This is to be expected in an organism that is highly adapted to a parasitic mode of existence. However, one cannot entirely rule out the uptake of these substances from the environment, since they may be released into the culture and subsequently assimilated as damaged host cells lyse. However, considerable uptake from this route appears unlikely, since there was little difference in growth rate between parasites propagated in $\mathrm{IO} / \mathrm{H}$, which is rich in nutrients, and IO2/HBSS, which has very little.

While the proportion of various salts and other substances varied somewhat between media, there was an

Table 3. Total iron and copper concentrations in various culture system compartments

\begin{tabular}{|lcccc}
\hline & Fresh medium & Used medium & G1B monolayer & Natural seawater $^{\mathrm{b}}$ \\
\hline Total iron $\left(\mu \mathrm{g} \mathrm{l}^{-1}\right)$ & 74 & 53 & 40 & $2-20$ \\
Total copper $\left(\mu \mathrm{g} \mathrm{l}^{-1}\right)$ & 13 & 11 & 2 & $1-90$ \\
a Assuming release of all metal in the cells into $5 \mathrm{ml}$ of culture medium & \\
b Weast (1964)
\end{tabular}




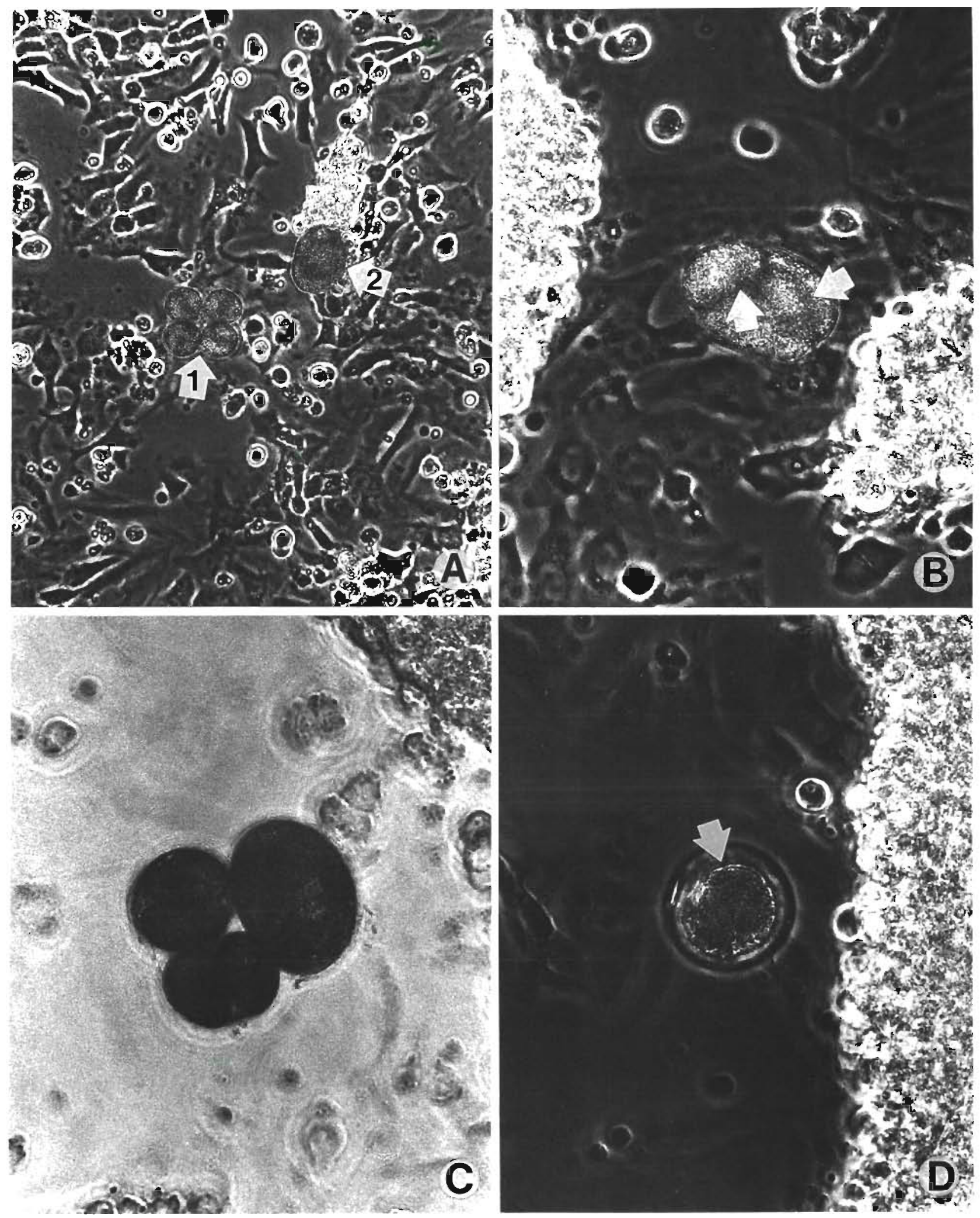

Fig 2. Amyloodinium ocellatum Morphology of normal and abnormal trophonts and tomonts in culture. (A) Normally dividing tomont (1) and normal trophont (2). Note attachment of trophont to a mass of host cells at 1 ts base. $(\times 2840)$ (B) Incompletely divided tomont Cleavage lines from attempted dıvisıons are present (arrows) $(\times 5700)$ (C) Tomont with an asynchronous divisıon rate $(\times 5700)$ (D) Dead tomont Note shrunkage of cytoplasmic contents away from periphery of cyst wall (arrow). ( $\times 5700)$ 
apparent range of osmolarity that was successful in propagating Amyloodinium ocellatum. H and HBSS, both less than $300 \mathrm{mOsm}$, did not allow continued survival of the parasites, although limited division occurred in HBSS (Table 2). Conversely, 10 and 102 , both greater than $800 \mathrm{mOsm}$, did not allow survival of G1B cells. HBSSM, with an osmolarity of $458 \mathrm{mOsm}$, allowed continued survival, but only very slow growth, of the parasites. However, osmolarity is not the sole determinant of A. ocellatum survival since IO2/HBSSA allowed vigorous growth of the parasite, even though it was the same osmolarity as HBSSM. This suggests that the relative proportions of various salts may be at least as important as the absolute concentrations of those salts. $\mathrm{IO} / \mathrm{H}$, IO2/HBSS, and IO2/HBSS-A have higher levels of $\mathrm{K}, \mathrm{Ca}, \mathrm{Mg}$, and $\mathrm{SO}_{4}$ compared to HBSSM (Table 1).

The ability of Amyloodinium ocellatum dinospores to differentiate into trophonts does not appear to be directly related to their ability to complete their life cycle. The media which produced the most rapid and highest percentages of dinospore differentiation (i.e. HBSS and HBSSM) were unable to support prolonged survival. Both trophont and tomont development were inhibited since there was both a greatly prolonged period of trophont attachment to the cell cultures as well as a decreased ability of tomonts to divide normally.

The selective inhibition of trophont and tomont development has never been reported. In fact, the dinospore is considered by far the most susceptible stage to chemotherapy (Lawler 1980, Lauckner 1984, Paperna 1984). Our results suggest that significant fluxes of major ionic constituents occur even while the parasite is attached to the host. Amyloodinium ocellatum penetrates into the host cell cytoplasm to feed (Lom \& Lawler 1973). The intracellular fluid of fishes varies considerably from that of seawater. For example, higher levels of $\mathrm{K}$ and lower levels of $\mathrm{Na}$ are typically present (Prosser 1973). Thus, intracellular fluid may not have the proper ionic constituency required for $A$. ocellatum and thus the parasite may need to regulate by exchanging ions from the environment. Determining what factors are inhibiting trophont growth and differentiation may provide methods of treating the parasites while on the host. This would be especially useful for eliminating latent amyloodiniasis, which appears to be common (Lawler 1980).

The plating efficiency data also suggest that both IO/ $\mathrm{H}$ and $\mathrm{IO} 2 / \mathrm{HBSS}$ are inhibitory to dinospore differentiation. If only $\mathrm{IO} / \mathrm{H}$ were inhibitory, it might be explained by the presence of serum, which is known to have many factors with antimicrobial activity. However, the inhibitory activity of IO2/HBSS was unexpected. While IO2/HBSS has slightly lower levels of glucose, bicarbonate, and phosphate compared to HBSS and HBSSM, IO/H has similar levels, suggesting that these differences are not influencing dinospore differentiation. Both IO2/HBSS and $\mathrm{IO} / \mathrm{H}$ have higher concentrations of several mineral ions, including $\mathrm{K}, \mathrm{Ca}$, $\mathrm{Mg}$, and $\mathrm{SO}_{4}$, compared to HBSS or HBSSM (Table 1). It is possible that certain mineral ions that are present in higher concentrations in $10 / \mathrm{H}$ and $102 / \mathrm{HBSS}$ may be inhibitory to dinospore differentiation while at the same time being stimulatory to parasite development at other life stages

Others have shown that the ratios of different minerals, such as $\mathrm{Ca}$ to $\mathrm{Mg}$, or monovalent to divalent ions, can influence the growth of dinoflagellates and other protists (Provasoli et al. 1954). Mineral levels have also been shown to be important influences on difiereniiation. Calcium and magnesium are required for encystment of Hartmanella rhysoides (Band 1963), while excessive levels of $\mathrm{Na}$ or $\mathrm{Mg}$ prevent metamorphosis of Naegleria gruberi from the amoeboid to the flagellated form (Willmer 1956). The application of such environmental manipulations to controlling ectoparasitic protozoa has received little attention. The discovery that very simple salt solutions can support Amyloodinium ocellatum survival in vitro may facilitate studying its precise ecological requirements and may help us to understand how environmental factors regulate hostparasite relationships in the ectoparasitic protozoa.

Acknowledgements. I thank W. Fisher and W. King for assistance with cell culture and Dr C. McGahan, K. Hedeen, and A. Grimes for assistance with the trace metal studjes. This work was sponsored by the Office of Sea Grant, NOAA, U.S Department of Commerce, under Grant \#\# NA86-AA-D-SG046 and the North Carolina Department of Administration. The U.S. Government is authorized to produce and distribute reprints for governmental purposes notwithstanding any copyright that may appear hereon.

\section{LITERATURE CITED}

Anon. (1985). Synthetic sea salts. Sea Scope 2: 1-4

Band, N. R. (1963). Extrinsic factors for encystation by the soil amoeba, Hartmanella rhysoides. J. Protozool 10: 101-106

Bower, C. E., Tumer, D. T., Biever, R. T (1987). A standardized method of propagating the marine fish parasite, Amyloodinium ocellatum. J. Parasit. 73: 85-88

Guillard, R. R. L., Keller, M. D. (1984). Cuituring dinoflagellates. In: Spector, D. L. (ed.) Dinoflagellates. Academic Press, New York, p. 391-442

Ham, R. G. (1965). Clonal growth of mammalian cells in a chemically defined, synthetic medium. Proc. natn. Acad. Sci. U.S.A. 53: $288-293$

Lauckner, G. (1984). Diseases caused by protophytans (algae) In: Kinne, O. (ed.) Diseases of marine animals, Vol. IV, Part 1. Biologische Anstalt Helgoland, Hamburg, p. 169-180

Lawler, A. R. (1980). Studies on Amyloodinium ocellatum (Dinoflagellata) in Mississippi Sound: natural and experimental hosts. Gulf Res. Rep. 6: 403-413 
Lom, J., Lawler, A. R. (1973). An ultrastructural study on the mode of attachment in dinoflagellates invading gills of Cyprinodontidae. Protistologica IX (2): 293-309

McGahan, M. C., Bito, L. Z (1983). Determination of copper concentration in blood plasma and in ocular and cerebrospinal fluids using graphite furnace atomic absorption spectroscopy. Analyt. Biochem. 135: 186-192

McGahan, M. C., Fleisher, L. N. (1986). A micromethod for the determination of iron and total iron-binding capacity in intraocular fluids and plasma using electrothermal atomic absorption spectroscopy. Analyt. Biochem. 156: 397-402

Merchant, R. J., Kahn, R. H., Murphy, W. H. (1964). Handbook of cell and organ culture, 2nd edn. Burgess Publishing Co., Minneapolis

Noga, E. J. (1987). Propagation in cell culture of the dinoflagellate Amyloodinium, an ectoparasite of marine fishes. Science 236: 1302-1304

Noga, E. J., Bower, C. E. (1987). Propagation of the marine dinoflagellate Amyloodinium ocellatum under germ-free conditions. J. Parasit. 73: 924-928

Noga, E. J., Hartmann, J. X. (1981). Establishment of cell lines from the walking catfish (Clarias batrachus) and develop- ment of a channel catfish (Ictalurus punctatus) virus vaccine. Can. J. Fish. Aquat. Sci. 38: 925-930

Paperna, I. (1984). Reproduction cycle and tolerance to temperature and salinity of Amyloodinium ocellatum (Brown 1931) (Dinoflagellida). Ann. Parasitol. Hum. Comp. 59: $7-30$

Prosser, C. L. (1973). Inorganic ions. In: Prosser, C. L. (ed.) Comparative animal physiology, Vol. 1 W. B. Saunders Co., Philadelphia, p. 79-110

Provasoli, L. (1958). Nutrition and ecology of protozoa and algae. Ann. Rev. Microbiol. 12: 279-308

Provasoli, L., McLaughlin, J. A., Pintner, I. J. (1954). Relative and limiting concentrations of major mineral constituents in the growth of algal flagellates. Trans. N.Y Acad. Sci. 16: $412-417$

Spotte, S. (1979). Seawater aquariums. John Wiley and Sons, New York

Weast, R. C. (ed.) (1964). Handbook of chemistry and physics. The Chemical Rubber Company, Cleveland

Willmer, E. N. (1956). Factors which influence the acquisition of flagellae by the amoeba, Naegleria gruberi. J. exp. Biol. 33: $583-603$

Responsible Subject Editor: Professor W. Körting; accepted for printing on February 16, 1989 